\title{
LABOUR INEQUALITIES IN EUROPE: THE CASE OF SERBIA
}

\section{Svetlana Mihic, Miroslava Filipovic, Danijela Dasic*}

\begin{abstract}
Gender differences present a topic of great interest in contemporary societies. Aim of this paper is to make a comparison between the unemployment in Serbia and the European countries, and to identify those countries which record the most similar performances considering gender and age. The research is conducted through analysis of activity rates, employment rates, unemployment rates, inactivity rates and long-term unemployment rates. The factor analysis enabled us to identify main factors that influence structures of the labour markets in Europe. Final result of this research is the recommendation of policy measures, including the promotion of women entrepreneurship, in order to reduce gender inequalities in contemporary society's economic activity.
\end{abstract}

Keywords: unemployment, gender inequalities, labour market, Europe, Serbia

JEL Classification: J60, J70

\section{Introduction}

It has been widely accepted that modern societies, particularly in Europe, strive to enhance gender equality as a condition for further economic development. At the same time, the level of accomplished gender equality has been used as an indicator of humanization of social relationships, the latter being considered as a dimension of general social prosperity (Kuburovic, 2007, p. 48).

The introduction of gender equality concept into theoretical models has formed a basis for further analysis of intra-gender relationships. Economic phenomena and processes are very often linked to demographic structures and processes, thus having gender sensitive character. It is therefore very important to monitor and research those processes with the aim of demographic processes management, enhancement of social security of both gender citizens and gender gap alleviating.

The relationship between genders is much affected by the process of modernization and macroeconomic social transformation. It is not unjustifiable to conclude that there is a prevailing tendency of gender inequality decrease in modern societies. Such changes have posed new questions referring to the existing differences between male - female positions thus opening space for new research and analyses from different points of view.

Devedzic (2007) emphasises that binary division influences series of phenomena and processes, many of them with demographic implications. It has been widely accepted that

* Svetlana Mihic, Goverment of Vojvodina, Serbia (svetlana.mihic@vojvodina.gov.rs);

Miroslava Filipovic, Faculty of economics, University EDUCONS, Serbia (miroslava.filipovic@ educons.edu.rs);

Danijela Dasic, Faculty of economics, University EDUCONS, Serbia (danijela.dasic@educons.edu.rs). 
the asymmetry of male and female economic activities is a proximate expression of double society code. Nevertheless, there is a question as to how much individual European countries differ between themselves regarding the gender aspect of economic activities, and where is Serbia in comparison to other countries. Devedzic (2007) also emphasises that economic structures provide numerous proofs of gender inequality, including with respect to the activity scope, employment and earnings. The largest reserves of labour are hidden in female workforce, but the share of female labour contingency usage in traditional societies is extremely small. In some countries husbands have legal rights to forbid their wives to work. However, a particular phenomenon is female non-paid work, extensively researched in gender studies.

Kuburovic (2007) starts his analysis with premises that economic and social power of women is lower in comparison to men, that gender inequality is a phenomenon not related to the degree of social development, and that social inequality of female and male population is diverse and multidimensional. The author puts special attention to former socialist countries emphasizing that negative consequences of structural social changes affected population of both genders, and that effects of social transformations are not gender neutral.

Kuburovic (2007) also emphasises the importance of economic structure analysis for it enables consideration of activity gender discordance, as an indicator of inequality of female and male positions, and one of dimensions of gender place in a society.

A considerable research in Serbia was done to analyse economical differences between gender and age groups, as in the field of demography, so as in the field of economy. Matkovic (2006) comments the setback of female social place in the countries of the Western Balkans emphasising that their economical position has deteriorated in comparison to the one in the previous social system of the countries (i.e. socialist system). This is substantiated by a higher unemployment of women than men, lower salaries, higher employment of women in less profitable sectors, less female occupation of management positions, and fewer women among entrepreneurs.

Djuric-Kuzmanovic (2002) concludes that there are different effects of labour market restructuring on economic and social gender positions in modern social - economic processes. There is a presumption that society transition differently affects position of women and men on the labour market. Considering demands of the market economy, i.e. offer increasing and demand decreasing for female labour, as well as disappearance of some benefits which existed in the previous social system, one can expect a further deterioration of women position and a gender gap widening in the future (Kuburovic, 2007, p. 69).

Analysing the EU countries, Huber (2009) discovers that there are important disparities in labour market movements considering gender and age, between the old member states (the EU15) and new members from the Eastern Europe (the EU12). He believes that a hypothesis of male labour being more affected on the labour market of the new EU member states, due to the changes of their economic structures and industry production decrease, should be tested. He concludes that there is a lower (than the EU15) rate of employed male population between ages of 25 to 54 in the countries 
of the Eastern Europe, while female and older population employment rates are more in accordance with the EU15. As far as the youngest and the oldest categories of labour force are concerned in the EU15 and the EU 12, these categories have a far better labour market position in the old EU countries. Upon this, Huber draws a conclusion that national institutions are almost the only factor that divides positions of the youngest and the oldest groups on the labour market of particular states.

Analysing the EU accession states, Knogler (2001) concludes that the CEEC states are not doing worse than the EU15 considering the most part of indicators. Some of the indicators have even been more favourable, referring to gender differences in employment and unemployment rates.

Research into economic activities of female and male population (age 15 and older) gives an insight into the economic positions of genders segments. Economic-activity population structure is significantly conditioned by demographic factors. It the same sense, gender differences in economic activity are the outcomes of age structure differences. Nevertheless, gender asymmetry of economic activity could be regarded as a result of unequal social gender positions, though this kind of inequality has been alleviated by the socialist model of gender equality, which is characterized by larger women entrance into the labour market and formal equalizing of genders in the right to work (Kuburovic, 2007, p. 23).

The first aim of this work is to identify where there are the largest differences between particular countries in Europe using a multivariant analysis of labour market from gender and age structures aspects. A starting hypothesis in the research is that there are very significant differences regarding women and men economic activities, and also regarding different age groups between particular states in Europe. The second aim is to use cluster analysis to find out which states have performances most similar to the labour market in Serbia with respect to gender and age structure. Finally, it aims to propose women entrepreneurship model as one of the ways to reduce gender economic disparities.

\section{General Overview of the Balkan Economic Scene}

For the purpose of this paper, we will consider the Balkan area as comprising the following countries: Serbia, Bosnia and Herzegovina, Macedonia, Montenegro, Croatia and Albania, as the nearest 'neighbourhood' of Serbia. Out of the former Yugoslav republics, Slovenia has been omitted because it joined the EU years ago, and had embraced different economic trends even during the existence of the former state. Contrary to that, Croatia has been included in this overview, since it has joined the EU a relatively short time ago, and had previously shared much of the experience of the former Yugoslav republics.

All of the countries have been experiencing difficult but varying paths of transition from socialist, self-managed economy to market economy. Unlike the former socialist countries from the Central Europe, the transition in the Balkans has not yet yielded (significant) economic gains. 


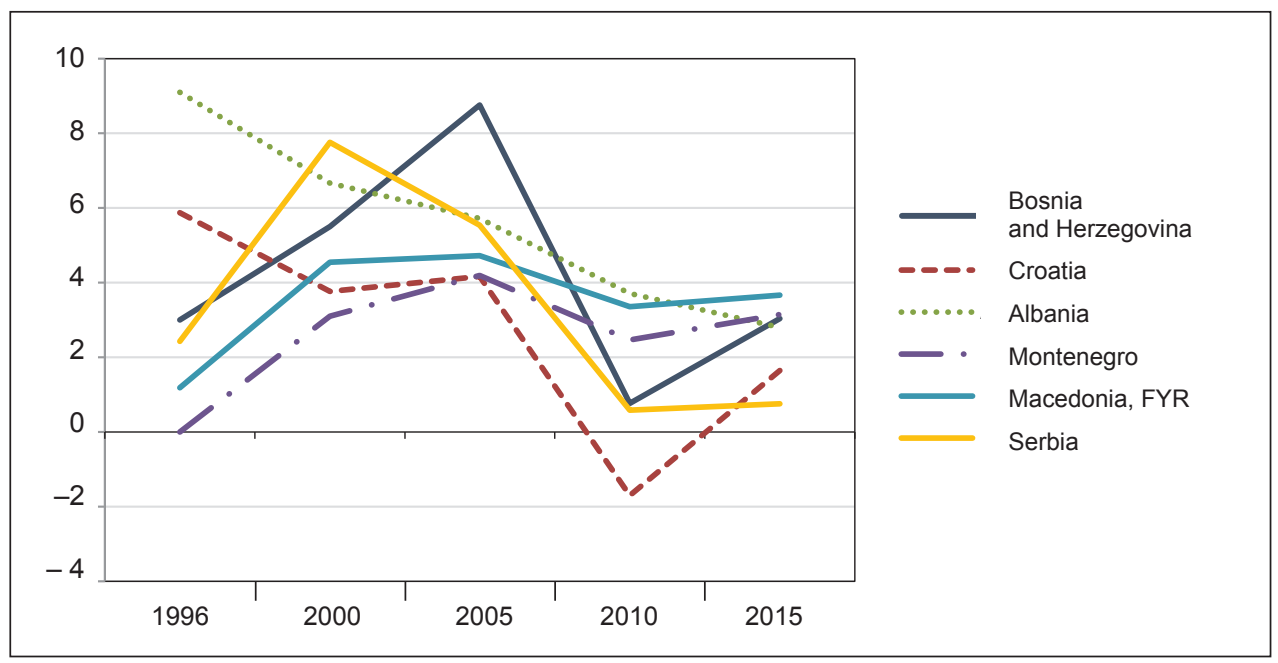

Source: www.data.worldbank.org

As seen in Figure 1, economic growth had been on a rising trend up to 2010, when the effects of the global economic crisis have started to show. Macedonia has recorded less volatility in the GDP growth, while Serbia recently recorded a rather slow economic recovery. According to the World Bank data, these countries have been facing large investment deficits during the transition period, and in 2015 the share of total external debt in comparison to Gross National Income (GNI) is very high: it ranges from $65 \%$ of GNI (Montenegro) to $88 \%$ (Serbia). Rising external debt adds inflationary pressures and further restraints to employment growth, particularly in the public sector. The latter has undergone significant restructuring (including massive lay-offs) but the public sector reform is far from finished in all the countries.

As far as the unemployment rate (to working age population) is concerned, the situation differs from country to country, but generally the ratio (in the period 2015/2016 ${ }^{1}$ ) has between 13\% and 25\%, more precisely: 13\% (Serbia), 14.2\% (Albania), 18.2\% (Croatia), 18.3\% (Montenegro), to 23.1\% (Macedonia) and even 25.4\% (Bosnia and Herzegovina). Data on gross wages paid is presented in the following table, except for Macedonia where data were not available.

As obvious from the Table 1, gross monthly average wages vary significantly among the countries in the Balkans, especially in the case of Albania and Croatia that present two extremes in this case. Despite critical problems in transition recorded in all the countries, one cannot neglect an important upward trend in gross wages. However, we must hold important reservation against such a conclusion, due to different financial burdens imposed on wages and different exchange rates mechanisms in place in the countries.

1 Due to various sources of data bases used in this research (World Bank and IMF), it is possible only to give an estimate for comparative purposes calculated by the authors. 
Table 1 | Gross Average Monthly Wages, by Country and Year, in USD (current nominal exchange rate)

\begin{tabular}{|l|c|c|c|c|}
\hline & $\mathbf{2 0 0 0}$ & $\mathbf{2 0 0 5}$ & $\mathbf{2 0 1 0}$ & $\mathbf{2 0 1 5}$ \\
\hline Albania & 92.9 & 200.2 & 334.6 & n.a. \\
\hline Bosnia and Herzegovina & 254 & 506.8 & 823.5 & 731.7 \\
\hline Croatia & 588.4 & 1050.3 & 1396.6 & 1173.7 \\
\hline Montenegro & n.a. & 406.2 & 947.9 & 804.4 \\
\hline Serbia & 69.5 & 382.4 & 610.5 & 561.9 \\
\hline
\end{tabular}

Source: UNECE Statistical Database, http://w3.unece.org (Accessed on May 5, 2017)

\section{Research Methods}

Data for the analysis is taken from the Internet site EUROSTAT for the year 2016 (Eurostat, 2016). Those are the latest available statistical data collected through national Labour Force Surveys. For some states, data is not available and those states have been omitted from the analysis (for example: Bosnia and Herzegovina, Estonia, Albania and Latvia). Data for Serbia is collected at the base of polling about labour for the year 2016 (Serbian Statistical Office, 2016).

The following attributes have been analysed: activity rate, employment rate, unemployment rate, inactivity rate and long-term unemployment rate. Each attribute has been separately analysed according to genders and age groups of ten years, beginning with 14 and ending with 65 years of age.

The factor analysis in this research has the following characteristics:

- Factor analysis is based at the analysis of the main components as a method of factor extraction.

- Five factors are selected by the analysis.

- Minimal eigenvalue amounts to 1 , which is the ordinary height of main components variance. That means that in factor rotation only those of eigenvalue higher of 1 would be included.

- After the first factor extraction, their rotation has been done according to varimax normalising method. This is the most popular method of factor rotation. Nevertheless, rotation has been done in order to make the factors easy for rendering.

\section{Research Results}

By factor analysis, five factors have been isolated, which together explain $91.68 \%$ variations of data. In other words, $91.67 \%$ variations on the labour market could be explained via the selected factors. Eigenvalues and share of explained variability are shown in Table 2. Attained solution provides a clear picture of the labour markets in Europe. The selected factor loadings are shown in Table 2. 
Table 2 | Eigenvalues and Share of Variability Explained by Five Factors

\begin{tabular}{|l|c|c|c|c|}
\hline Factor & Eigenvalue & Total variance (\%) & $\begin{array}{c}\text { Eigenvalue } \\
\text {-cumulative }\end{array}$ & $\begin{array}{c}\text { Variance- } \\
\text { cumulative (\%) }\end{array}$ \\
\hline $\mathbf{1}$ & 36.58961 & 48.95654 & 37.42685 & 48.95654 \\
\hline $\mathbf{2}$ & 15.85691 & 19.35342 & 49.20042 & 65.64852 \\
\hline $\mathbf{3}$ & 11.56214 & 15.85321 & 65.26119 & 73.80523 \\
\hline $\mathbf{4}$ & 5.42689 & 10.52691 & 71.84852 & 85.73775 \\
\hline $\mathbf{5}$ & 4.98521 & 6.58921 & 75.75262 & 91.67851 \\
\hline
\end{tabular}

Source: Authors' own statistical analysis

Factor 1 explains $48.95 \%$ of the variations in data and freely could be named as 'Female economic activity' for it incorporates variables linked to female gender in the most active age from 25 to 55, referring to activity rate, employment and inactivity. The obtained results lead to a clear conclusion that European labour markets differ mostly with regard to the economic activity of women. Factor 2 explains additional $19.35 \%$ of the variations on the labour markets. It integrates the influences of male employment rate at age from 25 to 50, and female unemployment rate at the youngest age of activity from 15 to 20. Thus, for this factor we could say that it integrates male employment rate and unemployment rate.

Factor 3 explains additional $15.85 \%$ of the variations, and clearly isolates rates of activity, employment, unemployment and inactivity for the oldest participants at the labour markets, ages from 55 to 65 , regardless the gender.

Factor 4 explains additional $10.52 \%$ of variations at the labour markets and it incorporates variables referring to male rate of activity and inactivity of ages from 30 to 55 . According to that, this factor could be named as 'Economic activity of men'.

Factor 5 explains additional $6.58 \%$ of the variations at the labour markets and clearly isolates the rates referring to the youngest groups of participants at the labour markets, regardless the gender.

Drawing upon the attained factor scores, a cluster analysis has been done and solution of 5 clusters is reached. The distribution between clusters is shown in the Table 3 .

After clusterization, the analysis of variance has been made in order to define if there is a statistically significant difference between clusters considering variables monitoring. It has been concluded that clusters do not differ among each other only with respect to male labour of age from 25 to 50 referring to activity and inactivity rates. In all other cases, there are statistically highly significant differences, which mean that a division into 5 clusters is essentially valid.

It became obvious that the labour market structures of Macedonia and Turkey were different from other states to the extent that they were put into individual clusters. Serbia was positioned in Cluster 1, together with a large number of the Eastern Europe states, as well as Belgium, Italy and France. Figure 2 shows the schedule of middle values for 82 monitored variables 
for Clusters 1,2 and 4. One can conclude that Cluster 1 shows the worst performances of the labour market for average rates of activity, employment rates are lower and rates of unemployment, inactivity and long-term unemployment, higher than those in Clusters 2 and 4.

Table 3 | Distribution of the European States per Clusters

\begin{tabular}{|l|l|l|l|l|}
\hline \multicolumn{1}{|c|}{ Cluster 1 } & \multicolumn{1}{|c|}{ Cluster 2 } & \multicolumn{1}{|c|}{ Cluster 3 } & \multicolumn{1}{|c|}{ Cluster 4 } & \multicolumn{1}{|c|}{ Cluster 5 } \\
\hline Belgium & Germany & Macedonia & Denmark & Turkey \\
Bulgaria & Ireland & & Holland & \\
Czech Republic & Spain & & Austria & \\
Greece & Cyprus & & Finland & \\
France & Latvia & & Sweden & \\
Italy & Portugal & & United Kingdom & \\
Hungary & & of Great & \\
Poland & & Britain and & \\
Romania & & Northern Ireland & \\
Slovenia & & Norway & \\
Slovakia & & Switzerland & \\
Croatia & & & & \\
Serbia & & & & \\
\hline
\end{tabular}

Source: Authors' own statistical analysis

Figure 2 | Average Values Distribution of Monitored Variables on the Labour Market for Clusters 1,2 and 4



Source: Authors' own statistical analysis 
Though all states feature a high level of women equality of rights as individuals in the public sphere, one can detect a low level of women equality as spouses in some states. Changes in family happen very slowly for the social system is linked to traditional institutions, as church for example. This link strengthens the family institution through idealized family morality (Devedzic, 2007, p. 71).

Figure 3 | Activity Rates of Women at Different Ages in Countries in Cluster 1



Source: Authors' own statistical analysis

Figure 3 shows the activity rate of women by age groups and countries from the first Cluster. The activity rate is the percentage of active population in total population aged 15 and over. Serbia (SR in the diagram) is represented by the thickest line, and shows that it ranks near the average when the main age group in the labour market is considered. The same analysis underscore that lower indicators are recorded for Italy (IT), Greece (EL) and Romania (RO). Serbia actually shows low activity for the youngest group of 20 to 40 years, while the maximum rate is reached at the age of 35 to 39 years of age.

\section{Emancipation of Women as a Factor of Economic Rate Acceleration}

Today, many consider women as the most powerful drivers of global economic growth. Enhanced employment of women, in several recent decades, has contributed to the World Domestic Product (WDP) increase. In developed countries, women produce slightly less 
than $40 \%$ of GDP, and if we add housework, they produce over a half of the total GDP (Petrović, 2007). Female work in the house is unpaid, and they do not receive health and pension assurance. With economic growth, it is expected that a rise of women's influence will occur in all social domains.

Figure 4 | Ministers of the Republic of Serbia Government, Structure per Gender, 2002-2016

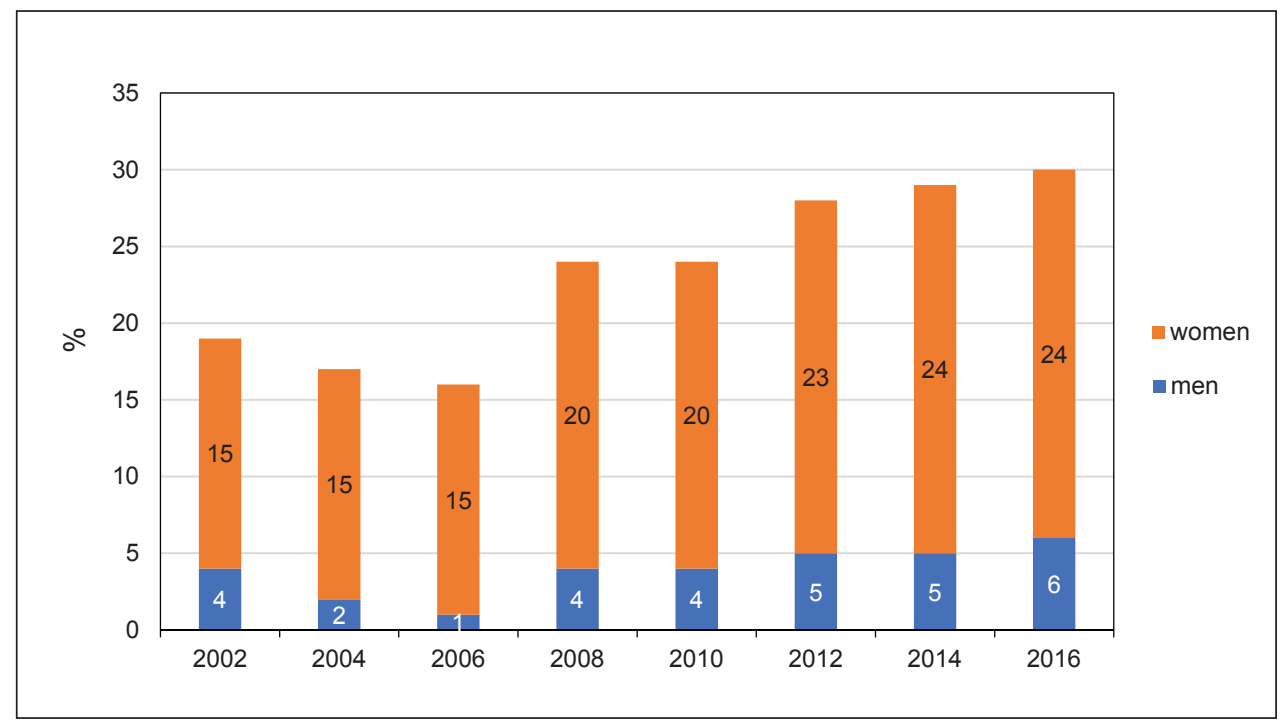

Source: Government of the Republic of Serbia, authors' own statistical analysis

The average life expectancy of men is 59 in CEE states, while it is 63 in Ukraine 2 . Main reasons behind this indicator are a lack of adequate health care, unemployment, unhealthy food and excessive drinking. The average life expectancy of women in the EU is six years longer than men. Though, on the other side, there is a trend of living standards improvement with inter alia positive image of older age being developed, linked to the above mentioned age factors and negative population growth. This contributes to a comprehension of CEE women of older age as a "social avant-garde". They have a relatively good access to education and employment. Women are at the forefront of highskilled labour contingent in these states measured by formal education. Owing to their traditional roles, sectors of commerce and consumption are more familiar to them then to men, i.e. spending rationally and saving as much as possible. In Germany, women take up $80 \%$ of the consumption and in the CEE states this share is even higher.

From the global market aspect, women are still a largely underused resource. The last several decades in Serbia saw an increase in the importance of women employment, together with a negative population growth and drastic aging of population. The latest labour survey

2 Source: www.worldlifeexpectancy.com/ accessed 11.5.2017 
in Serbia indicates that two fifths of women are now employed (Nikolic, 2007). Figure 5 presents the level of activity as to population gender older than 15 years in the period of $1996-2016$. In $2016,65 \%$ of men and about $43 \%$ of women were employed.

Figure 5 | Activity and Gender of Population Older than 15, 1996-2016, \%

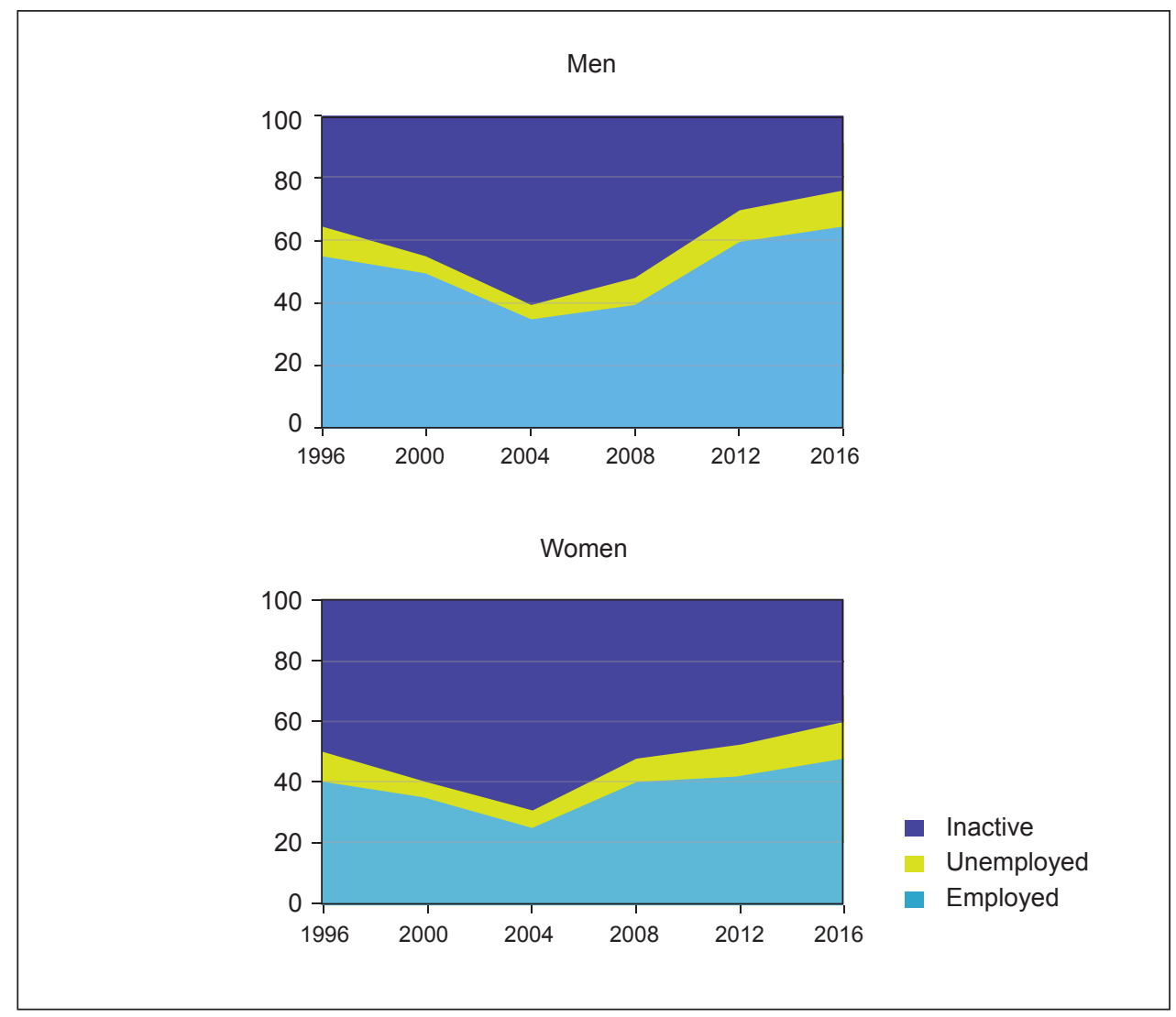

Source: Government of the Republic of Serbia, authors' own statistical analysis

As to employment structure in the public sector, especially in education and health sectors, more women than men are employed, while in all other fields of economic and social life employment of women is at a very low level. The largest 'losers' in the process of transition of Serbia are women in their fifties, though, there is an encouraging trend of great demand for women in their late twenties and early thirties due to their accomplishments (Nikolic, 2007). Today, throughout the Western Europe and the US, women are equal to men from the legal point of view. They are equal referring to job application, social assurance, earning, and education. In reality, practical realisation of these rights is very complicated, so that the overall social status of women is more unfavourable in comparison to men. 
There is a significant variance between proclaimed principles and concrete practice. For example, in the Republic of Serbia in December 2016, a woman has an average wage of 383.00 euro, while a man has 442.00 euro (Republic of Serbia Institute for Statistics, 2016). It should not be forgotten that circumstances are difficult for women in Serbia, i.e. there are basic barriers of gender equality, strong patriarchal conscience and religious preconceptions.

\section{Women Entrepreneurship}

It is widely held that entrepreneurship is a motor of economic development, and it is necessary to create conditions for entrepreneurship to grow and develop. One of the development paths, which could also contribute to reducing gender economic disparities, includes an underused resource of women entrepreneurship. Since the changes of the Serbian political system in 2000, economic reforms and restructuring have gained in speed. Along with this there came a significant rise of the entrepreneurship sector although with certain difficulties in establishment of the entrepreneurial social strata (Laic, 2011). Political and economic changes have opened up more opportunities for women to register and manage companies (Bubonic, 2007).

Women entrepreneurship has been in expansion worldwide and the impact of globalization on gender inequalities has been extensively researched. Most of the research underscore that over $75 \%$ of women start their business to gain financial independence. According to one research, more than $60 \%$ of women entrepreneurs are in the textile sector, $13 \%$ are in the food industry, $11 \%$ engage in trade and services, while $16 \%$ of female entrepreneurs provide services related to cosmetics, beauty and tourism (Grozdanić, 2014).

If women entrepreneurship is to be promoted, it is necessary to stimulate its rise on various levels, including young female population at schools and those already present on the labour market (Hart, Gatewood and Carter, 2014).

There are several ways to assess the extent of women entrepreneurship: through the share of women in total number of entrepreneurs, the share of female entrepreneurs in total employment numbers, etc. Available EU data show that economic potential of women is still underused. Of all active companies and entrepreneurs, women entrepreneurship accounts for only $28 \%$, while only $19.6 \%$ of active women have their own business in comparison to $33.1 \%$ of active men (http://ec.europa.eu/small-business-act/index_en.htm, accessed on May 11, 2017.). A significant rise of women entrepreneurship in Serbia since 2000, and particularly since 2006, is presented in the following figures: 


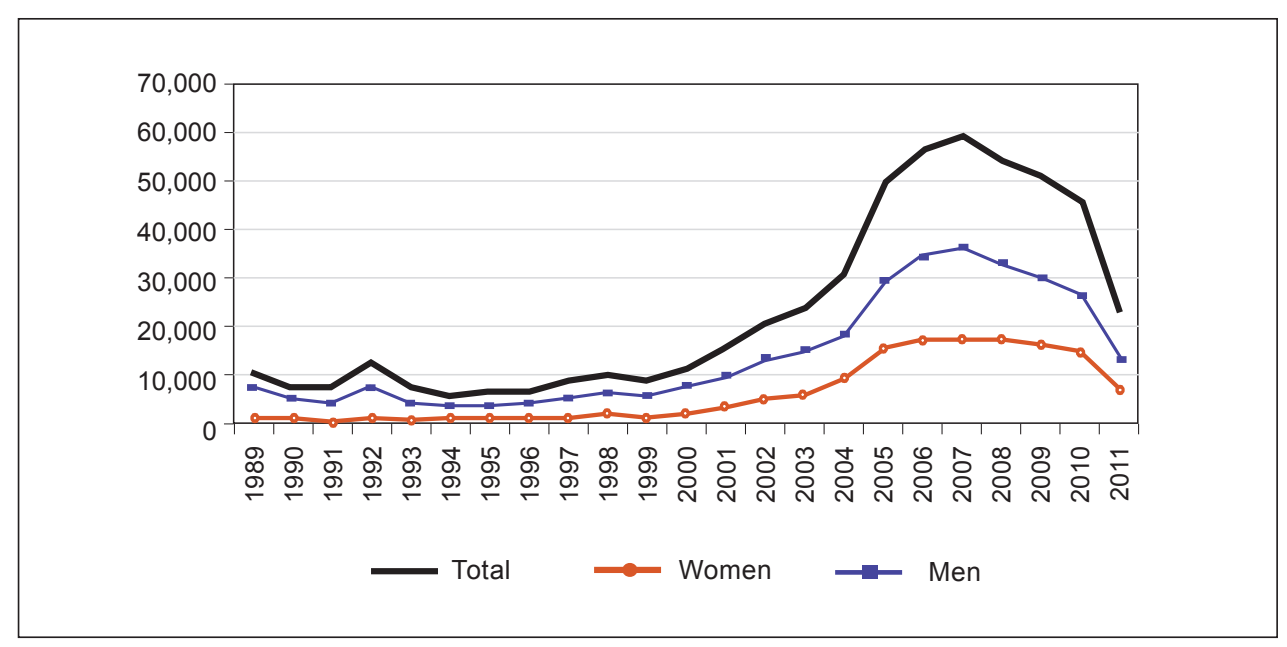

Source: http://webrzs.stat.gov.rs. (Accessed on May 11, 2017.); authors' own statistical analysis

Figure 7 | Start-Ups in Serbia by Gender and Average Number of owner in 000, 2000-2013

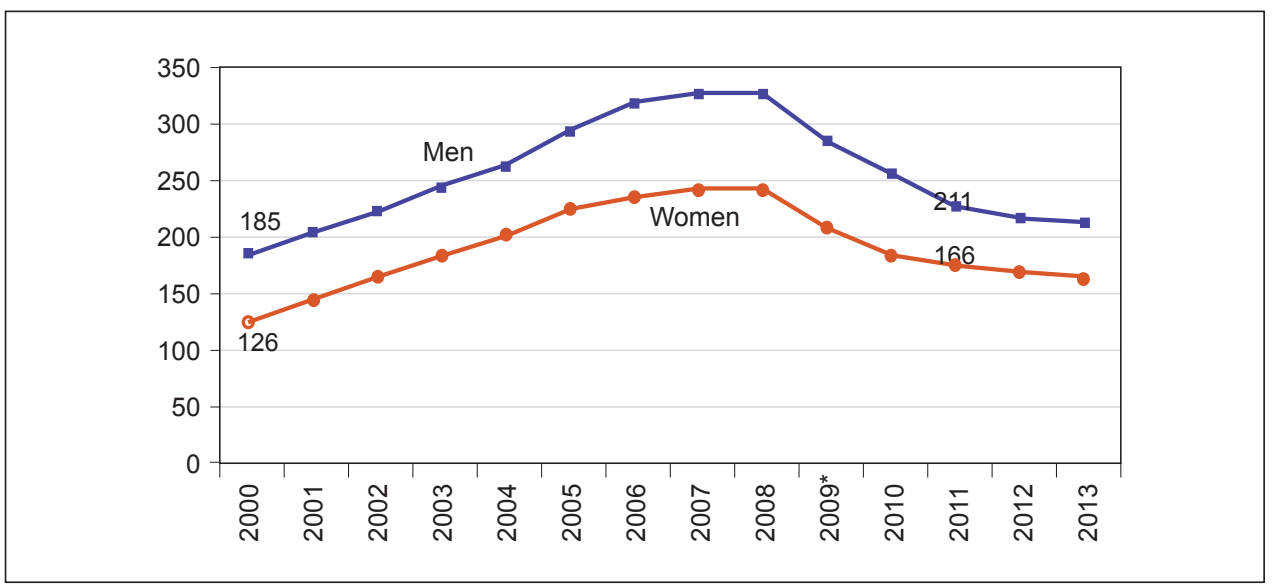

Source: http://webrzs.stat.gov.rs. (Accessed on May 11, 2017.), authors' own statistical analysis

The extent of women entrepreneurship in Serbia was assessed on the basis of official data from the Serbian Statistical Office. A conclusion that follows is that the Serbian entrepreneurial sector is being dominated by men, but recently that trend has started to change, as more and more women decide to gain shares in businesses. A research conducted by the Serbian Association of Business Women and the Association for female initiative concludes that women potential and education have not been adequately used either in the economy or in the sectors which affect women entrepreneurship. 
Table 4 | Active Companies by Founder's Gender

\begin{tabular}{|l|c|c|}
\hline Founded in & Women & Men \\
\hline $\mathbf{1 9 8 9 - 1 9 9 5}$ & 8.7 & 14.2 \\
\hline $\mathbf{1 9 9 6 - 2 0 0 0}$ & 8.2 & 10.2 \\
\hline $\mathbf{2 0 0 1 - 2 0 0 5}$ & 24.0 & 24.5 \\
\hline $\mathbf{2 0 0 6 - 2 0 1 0}$ & 59.1 & 51.1 \\
\hline $\mathbf{2 0 1 1 - 2 0 1 4}$ & 60.9 & 65.8 \\
\hline $\mathbf{2 0 1 4 - 2 0 1 6}$ & 61.3 & 66.1 \\
\hline
\end{tabular}

Source: http://webrzs.stat.gov.rs. (Accessed on May 10, 2017)

Table 5 | Entrepreneurship Rates by Gender and Start-Up Maturity

\begin{tabular}{|c|c|c|c|c|c|c|c|}
\hline & \multicolumn{2}{|c|}{$\begin{array}{c}\text { Early start-up } \\
3-42 \text { months } \\
\text { of activity }\end{array}$} & \multicolumn{2}{|c|}{$\begin{array}{l}\text { Start-up with } \\
\text { activity longer } \\
\text { than } 42 \text { months } \\
\text { (established } \\
\text { business) }\end{array}$} & \multicolumn{2}{|c|}{$\begin{array}{l}\text { Total entre- } \\
\text { preneurship rate } \\
\text { (early + estab- } \\
\text { lished business) }\end{array}$} & \multirow{2}{*}{$\begin{array}{c}\text { Women entre- } \\
\text { preneurship } \\
\text { rank, by eco- } \\
\text { nomic necessity } \\
\text { motive* } \\
-\end{array}$} \\
\hline & $M$ & $\mathbf{F}$ & M & $\mathbf{F}$ & M & $\mathbf{F}$ & \\
\hline Serbia & 12.3 & 5.2 & 7.6 & 2.9 & 19.9 & 8.1 & 1 \\
\hline Czech Republic & 7.8 & 3.3 & 8.6 & 2.8 & 16.4 & 6.1 & 15 \\
\hline Slovenia & 7.2 & 2.9 & 7.3 & 3.1 & 14.5 & 6.0 & 32 \\
\hline Croatia & 9.3 & 5.2 & 5.9 & 2.9 & 15.2 & 8.1 & 3 \\
\hline Greece & 8.4 & 3.7 & 14.9 & 12.4 & 23.3 & 16.1 & 36 \\
\hline Hungary & 9.4 & 4.7 & 5.9 & 3.9 & 15.3 & 8.6 & 12 \\
\hline Denmark & 6.4 & 4.9 & 8.7 & 3.6 & 15.1 & 8.5 & 41 \\
\hline Italy & 6.9 & 3.5 & 9.0 & 2.4 & 15.9 & 5.9 & 26 \\
\hline Netherlands & 7.0 & 4.0 & 8.8 & 4.6 & 15.8 & 8.6 & 33 \\
\hline Portugal & 12.3 & 6.3 & 10.1 & 4.9 & 22.6 & 11.2 & 35 \\
\hline Romania & 5.0 & 3.5 & 3.6 & 2.4 & 8.6 & 5.9 & 22 \\
\hline Sweden & 5.9 & 2.7 & 7.0 & 2.8 & 12.9 & 5.5 & 25 \\
\hline UK & 7.6 & 3.9 & 7.8 & 2.7 & 15.4 & 6.6 & 24 \\
\hline Norway & 8.8 & 4.5 & 8.6 & 3.7 & 17.1 & 8.1 & 40 \\
\hline
\end{tabular}

Note: ${ }^{*}$ http://ec.europa.eu/small-business-act/index_en.htm., accessed on December 11, 2017. Rank is given "random" because Eurostat compares 45 countries and these rank are only for countries that were compared in GEM 2016/2017.

Source: Allen et al., GEM 2015/2016\& EUROSTAT 2016/2017 
By comparing data on women entrepreneurship in the EU and the neighbouring region, one can get a clear picture of Serbia's international position with respect to women entrepreneurship.

Analysis of the GEM data shows that the Republic of Serbia records rates of women entrepreneurship similar to those of Denmark and Norway. Nevertheless, when motives for engaging in entrepreneurship are considered, it becomes clear that Serbian women become entrepreneurs because of the economic necessity and the need to attain economic independence. That is not the situation as in Denmark and Norway, where the entrepreneurship idea is mostly considered as a business opportunity.

Figure 8 | Self-Employed Population in the EU and Serbia, 2016



Source: http://ec.europa.eu (Accessed on May 10, 2017.), http://webrzs.stat.gov.rs

(Accessed on May 10, 2017.), authors' own statistical analysis.

The data justifies a conclusion that both men and women engage in entrepreneurship more in Serbia than in the EU. Women entrepreneurship grows more rapidly in countries were female entrepreneurs are predominantly motivated by wealth increase, long-term financial security, success and appreciation, in comparison to countries where that is not the case (Orser, Riding and Manley, 2006). Women in developed countries have a clearer sense of costs and benefits from women entrepreneurship growth, and they make their business decision prudently (Brunni, Gherardi and Paggio, 2004). 


\section{Conclusion}

Analysis of gender differences in the economic area is as old as scientific disciplines, which research them (Demography, Sociology, Economics, etc.). The results of our research lead to a conclusion that gender regimes lay in the background of economic relationships between genders. These regimes could be justifiably used as a key to interpret rate differences between particular states considering basic labour market indicators.

According to OECD Report (2003), a large number of OECD states record a high share of work-inactive women.

Drawing on the experience of states with similar gender and age labour-market structures, it is possible to make conclusions which could be helpful for Serbian labour market development. Research conducted in some states clearly emphasizes a need to formulate labour market policy conducive to gender differences reduction, in both paid and unpaid work. With this gap reduction women work possibilities on labour market will increase. Measures which would influence distribution of unpaid work within a family and promote a model of equality in obligation sharing would lead to a larger women's participation at the labour market.

Based on the research results and the experience of states with almost identical problems on labour market as in Serbia, we can make a final conclusion. In order to start reducing the existent gender differences in activity and employment rates, the following measures should be undertaken:

- Considering the importance of unpaid work (housework and children rising) by women who do not participate in labour market, it is necessary to undertake measures which would reduce difficulties of the unpaid work and distribute it more evenly within families. Besides, the provision of certain public services could be of a great importance for women inactivity reduction.

- Working-hours change is very important for a great number of women for many of inactive women that could accept job with shorter or more flexible working time. Because of that, measures which would support jobs with shorter or flexible working time should be planned for, in order to avoid negative effects on professional careers of women or in unequal distribution of unpaid work within families.

- In regions with a lower rate of women unemployment, many inactive women are not properly motivated to enter the labour market from the beginning. Because of that measures should be undertaken to support higher women employment and to improve labour market institutions in order to balance work supply and demand. Those measures would provide higher inflow of female labour into the labour market.

- If women entrepreneurship is to be promoted, it is necessary to stimulate its rise on various levels, including young female population at school and those already present on the labour market. 


\section{Appendix}

\section{Factor Loadings}

\begin{tabular}{|c|c|c|c|c|c|}
\hline Age & Factor 1 & Factor 2 & Factor 3 & Factor 4 & Factor 5 \\
\hline \multicolumn{6}{|c|}{ Activity rate - women } \\
\hline $15-19$ & 0.26759 & -0.32496 & -0.52678 & 0.077945 & 0.89013 \\
\hline $20-24$ & 0.53051 & -0.23540 & -0.67452 & 0.470114 & 0.85162 \\
\hline $25-29$ & 0.91245 & -0.35125 & -0.27505 & 0.349432 & 0.42590 \\
\hline $30-34$ & 0.90765 & -0.35437 & -0.34685 & 0.236714 & 0.09954 \\
\hline $35-39$ & 0.88281 & -0.07556 & -0.05701 & 0.065507 & 0.03598 \\
\hline $40-44$ & 0.98765 & -0.09709 & 0.00203 & 0.098896 & -0.04955 \\
\hline $45-49$ & 0.99348 & -0.23577 & -0.05882 & 0.098915 & 0.07355 \\
\hline $50-54$ & 0.98332 & -0.25502 & -0.28055 & 0.24756 & 0.26851 \\
\hline $55-59$ & 0.65289 & -0.27895 & -0.75207 & 0.20689 & 0.52889 \\
\hline $60-64$ & 0.32585 & -0.34087 & -0.97785 & -0.05957 & 0.41981 \\
\hline \multicolumn{6}{|c|}{ Activity rate - men } \\
\hline 15-19 & -0.04567 & -0.29321 & -0.55001 & 0.113567 & 0.88521 \\
\hline $20-24$ & 0.18521 & -0.15851 & -0.58521 & 0.136571 & 0.82691 \\
\hline $25-29$ & 0.18531 & 0.01295 & 0.27881 & 0.428921 & 0.72640 \\
\hline $30-34$ & 0.23358 & -0.03954 & 0.31250 & 0.836914 & 0.55853 \\
\hline $35-39$ & 0.05351 & 0.05621 & -0.07001 & 0.944593 & 0.28534 \\
\hline $40-44$ & 0.09587 & -0.18510 & -0.18523 & 0.955297 & 0.31205 \\
\hline $45-49$ & 0.38932 & 0.01171 & -0.38510 & 0.795310 & 0.01005 \\
\hline $50-54$ & 0.75713 & -0.02156 & -0.51001 & 0.699081 & 0.06118 \\
\hline $55-59$ & 0.52189 & 0.05862 & -0.69531 & 0.489510 & 0.29886 \\
\hline $60-64$ & -0.02839 & -0.01521 & -0.93581 & 0.199482 & 0.28655 \\
\hline \multicolumn{6}{|c|}{ Employment - women } \\
\hline 15-19 & 0.15823 & -0.28596 & -0.39575 & 0.196510 & 0.81952 \\
\hline $20-24$ & 0.53628 & -0.54551 & -0.45559 & 0.299531 & 0.59652 \\
\hline $25-29$ & 0.85213 & -0.51050 & -0.27851 & 0.159614 & 0.19998 \\
\hline $30-34$ & 0.95121 & -0.49853 & -0.15871 & 0.079999 & 0.14126 \\
\hline $35-39$ & 0.89530 & -0.39851 & -0.09522 & 0.045921 & 0.11020 \\
\hline $40-44$ & 0.85328 & -0.49101 & -0.12056 & 0.065910 & 0.11561 \\
\hline 45-49 & 0.95590 & -0.45621 & -0.09521 & 0.101051 & 0.19541 \\
\hline $50-54$ & 0.75697 & -0.41560 & -0.35954 & 0.128891 & 0.29531 \\
\hline 55-59 & 0.63385 & -0.36927 & -0.69581 & 0.190110 & 0.39995 \\
\hline $60-64$ & 0.33130 & -0.29991 & -0.79953 & -0.059651 & 0.39745 \\
\hline
\end{tabular}


Factor Loadings - continuation

\begin{tabular}{|c|c|c|c|c|c|}
\hline \multicolumn{6}{|c|}{ Employment rate - men } \\
\hline $15-19$ & 0.01029 & -0.29561 & -0.21142 & 0.159515 & 0.89995 \\
\hline $20-24$ & 0.59610 & -0.61005 & -0.45597 & 0.131595 & 0.68954 \\
\hline $25-29$ & 0.39811 & -0.65891 & 0.10505 & 0.166920 & 0.45225 \\
\hline $30-34$ & 0.29725 & -0.75610 & 0.05954 & 0.359531 & 0.19559 \\
\hline $35-39$ & 0.28551 & -0.95510 & -0.09621 & 0.399856 & 0.11050 \\
\hline $40-44$ & 0.45520 & -0.75921 & -0.12895 & 0.458961 & 0.09991 \\
\hline $45-49$ & 0.41523 & -0.95629 & -0.23561 & 0.695210 & 0.05651 \\
\hline $50-54$ & 0.49756 & -0.59510 & -0.39851 & 0.558562 & 0.09651 \\
\hline $55-59$ & 0.51003 & -0.40950 & -0.88956 & 0.425568 & 0.25359 \\
\hline $60-64$ & 0.01019 & -0.20150 & -0.89990 & 0.122589 & 0.30900 \\
\hline \multicolumn{6}{|c|}{ Unemployment rate - women } \\
\hline $15-19$ & -0.05150 & 0.59956 & 0.28651 & -0.105836 & -0.65210 \\
\hline $20-24$ & -0.50262 & 0.79590 & 0.18569 & -0.041519 & -0.34451 \\
\hline $25-29$ & -0.29518 & 0.95826 & 0.25610 & 0.059651 & -0.29551 \\
\hline $30-34$ & -0.34594 & 0.89992 & 0.22551 & 0.077569 & -0.24551 \\
\hline $35-39$ & -0.29884 & 0.95562 & 0.25890 & 0.089991 & -0.35100 \\
\hline $40-44$ & -0.28961 & 0.95582 & 0.10523 & 0.058961 & -0.20501 \\
\hline $45-49$ & -0.15569 & 0.96999 & 0.24591 & 0.078952 & -0.25625 \\
\hline $50-54$ & -0.05668 & 0.99968 & 0.24459 & 0.069524 & -0.22530 \\
\hline $55-59$ & 0.09531 & 0.99956 & 0.25961 & 0.138951 & -0.17750 \\
\hline $60-64$ & 0.12256 & 0.79953 & 0.15621 & 0.456210 & -0.05559 \\
\hline \multicolumn{6}{|c|}{ Unemployment rate - men } \\
\hline $15-19$ & -0.12591 & 0.75632 & 0.15693 & -0.344921 & -0.45960 \\
\hline $20-24$ & -0.56992 & 0.89652 & 0.12896 & -0.078951 & -0.29995 \\
\hline $25-29$ & -0.52131 & 0.98895 & 0.12596 & -0.045621 & -0.12955 \\
\hline $30-34$ & -0.35951 & 0.96521 & 0.15962 & -0.596661 & -0.18965 \\
\hline $35-39$ & -0.56691 & 0.99562 & 0.05592 & -0.044883 & -0.33351 \\
\hline $40-44$ & -0.52461 & 0.99531 & 0.09981 & -0.089621 & -0.03565 \\
\hline $45-49$ & -0.35591 & 0.95610 & 0.07023 & -0.129656 & -0.06995 \\
\hline $50-54$ & -0.29553 & 0.98652 & 0.09561 & -0.133695 & -0.04562 \\
\hline $55-59$ & -0.10551 & 0.85620 & 0.05691 & -0.077955 & 0.05556 \\
\hline $60-64$ & -0.22295 & 0.95589 & -0.05631 & 0.069851 & 0.06669 \\
\hline \multicolumn{6}{|c|}{ Inactivity rate - women } \\
\hline 15-19 & -0.56510 & 0.32251 & 0.52693 & -0.099955 & -0.88561 \\
\hline $20-24$ & -0.53861 & 0.53210 & 0.49419 & -0.239659 & -0.75612 \\
\hline
\end{tabular}


Factor Loadings - continuation

\begin{tabular}{|c|c|c|c|c|c|}
\hline $25-29$ & -0.88851 & 0.26351 & 0.19953 & -0.235585 & -0.31585 \\
\hline $30-34$ & -0.96885 & 0.24569 & 0.15689 & -0.126986 & -0.08965 \\
\hline $35-39$ & -0.88521 & 0.10521 & 0.04901 & -0.096520 & -0.08895 \\
\hline $40-44$ & -0.88961 & 0.15632 & -0.01001 & -0.099955 & 0.03985 \\
\hline $45-49$ & -0.89521 & 0.11056 & 0.06961 & -0.098996 & -0.09885 \\
\hline $50-54$ & -0.89523 & 0.15629 & 0.12896 & -0.149651 & -0.25951 \\
\hline 55-59 & -0.65321 & 0.19856 & 0.69510 & -0.166655 & -0.31908 \\
\hline $60-64$ & -0.33481 & 0.24848 & 0.95231 & 0.059961 & -0.35101 \\
\hline \multicolumn{6}{|c|}{ Inactivity rate - men } \\
\hline $15-19$ & 0.03362 & 0.28951 & 0.38961 & -0.172952 & -0.95625 \\
\hline $20-24$ & -0.15896 & 0.15681 & 0.55689 & -0.210051 & -0.58921 \\
\hline $25-29$ & -0.20182 & -0.01005 & -0.29871 & -0.389921 & -0.75925 \\
\hline $30-34$ & -0.15896 & 0.06925 & -0.13512 & -0.900121 & -0.42531 \\
\hline $35-39$ & -0.06321 & -0.08489 & 0.12520 & -0.955691 & -0.39563 \\
\hline $40-44$ & -0.08545 & 0.51003 & 0.25669 & -0.752159 & -0.56987 \\
\hline $45-49$ & -0.39982 & -0.01005 & 0.43289 & -0.945910 & -0.01093 \\
\hline $50-54$ & -0.64689 & 0.02519 & 0.49940 & -0.881961 & -0.08155 \\
\hline $55-59$ & -0.51258 & -0.05932 & 0.85904 & -0.589120 & -0.31286 \\
\hline $60-64$ & 0.09926 & 0.01148 & 0.99906 & -0.332121 & -0.52149 \\
\hline \multicolumn{6}{|c|}{ Long-term unemployment rate } \\
\hline Women 15-64 & -0.05885 & 0.59581 & 0.55392 & 0.069315 & -0.50505 \\
\hline Men 15-64 & 0.07256 & 0.7233 & 0.49458 & -0.055934 & -0.49548 \\
\hline
\end{tabular}

Source: Authors' own statistical analysis

\section{References}

Adsera, A. (2004). Changing Fertility Rates in Developed Countries. The Impact of Labor Market Institutions. Journal of Population Economics, 17(1), 17-43, https://doi.org/10.1007/ s00148-003-0166-x

Allen, I., Elam, A., Langowitz, N., Dean, M. (2007). Report on Women and Entrepreneurship. Babson, London: Global Entrepreneurship Monitor.

Babović, M. (2007). The Position of Women in the Labor Market in Serbia. UNDP Beograd.

Berlinski, S., Galliani, S. (2007). The Effect of a Large Expansion of Pre-primary School Facilities on Preschool Attendance and Maternal Employment. Labor Economics, 16(6), 665-680, http://doi.org/10.1016/j.labeco.2007.01.003

Bettio, F., Villa, P. (1998). A Mediterranean Perspective on the Breakdown of the Relationship between Participation and Fertility. Cambridge Journal of Economics, 22(2), 137-171, https://doi.org/10.1093/oxfordjournals.cje.a013708 
Brunni, A., Gherardi, S., Paggio, B. (2004). Entrepreneur-Mentality, Gender and the Study of Women Entrepreneurs. Journal of organizational change Management, 17(3), 236-268, https://doi.org/10.1108/09534810410538315

Devedžić, M. (2007). Gender (in) Equality of Demographic Perspective. Population, 45(2), 65-87, https://doi.org/10.2298/STNV0702063D

Elhorst, J. P. (2003). The Mystery of Regional Unemployment Differentials: Theoretical and Empirical Explanations. Journal of Economic Surveys, 17(5), 709-748, https://doi. org/10.1046/j.1467-6419.2003.00211.x

Grozdanić, R. (2014). Women's Entrepreneurship. Privredna komora Beograd.

Hart, M., Green, P., Gatewood, E., Brush, C., Carter, N. (2014). Women Entrepreneurship: Moving Front and Center. An Overview of Research and Theory. Available at: http://www.unm. edu/ asalazar/Kauffman/Entrep_research/e_women.pdf

Knogler, M. (2001). The Labor Markets of the Candidate Countries against the Backdrop of the EU Eastward Enlargement. Osteruopa-Institut Working Papers No. 228, 89-96.

Kuburović, A. (2007). Gender Inequality Is an Example of Socio-demographic Structure of the Population of Belgrade. Population, 45(1), 47-77, https://doi.org/10.2298/ STNV0701047K

Lazić, M. (2011). Waiting for Capitalism: The Emergence of New Class Relations in Serbia. Official Gazette of Belgrade.

Leschke, J., Jepsen, M. (2009). Transitional Labour Markets, From Theory to Policy Application. Can Transitional Labour Markets Contribute to a Less Traditional Gender Division of Labour? Centre d'Economie de la Sorbonne Working Papers No. 27, 127-138. Documents de travail du Centre d'Economie de la Sorbonne 2009.27 - ISSN 1955-611X. 2009. $<$ halshs-00384510>

Matković, G. (2006). Overview of Poverty and Social Exclusion in the Western Balkans. Population, 44(1), 7-46, https://doi.org/10.2298/STNV0601007M

Nikolic, G. (2007). Feminization of the Serbian Economy Leads Accelerating Economic Growth. E-magazine, 2, 27-36.

OECD (2003). The Labour Mobilisation Challenge: Combating Inactivity Traps and Barriers to Moving up Job Ladders, https://doi.org/10.1787/empl_outlook-2003-en

Orser, B., Riding, A., Manley, K. (2006). Women Entrepreneurs and Finance Capital. Entrepreneurship Theory and Practice, 30(5), 643-665, https://doi. org/10.1111/j.1540-6520.2006.00140.x 